http://journal.uinsgd.ac.id/index.php/biodjati

\title{
NOCTURNAL COLEOPTERA AND HEMIPTERA DIVERSITY AT GIAM SIAK KECIL BUKIT BATU BIOSPHERE RESERVE INDONESIA
}

\begin{abstract}
Hasni Ruslan ${ }^{*}$, Imran S. L. Tobing ${ }^{2}$
Selected paper from the $6_{\text {th }}$ Seminar Nasional Biologi (SEMABIO), Bandung-Indonesia, July 15, 2021 (conference.bio.uinsgd.ac.id) Received : September 26, 2021 Accepted : November 06, 2021 DOI: 10.15575/biodjati.v6i2.14102 ${ }^{1,2}$ Faculty of Biology, Universitas Nasional, Jl. Sawo Manila Pejaten, Jakarta, Indonesia, 12550

e-mait:

*1hasniruslan@yahoo.co.id

²imrantobing@unas.ac.id

*Corresponding author

Abstract. Giam Siak Kecil Bukit Batu is a biosphere reserve which one of its functions is as a habitat for wildlife. However, biodiversity data in the Giam Siak Kecil Bukit Batu Biosphere Reserve (GSKBB-BR) is still very minimal, including insects (Coleoptera and Hemiptera). This research was conducted to determine the diversity of Coleoptera and Hemiptera in the GSKBB Biosphere Reserve, Riau, Indonesia. The research was carried out using an exploratory method using "lights trap". The results of the study found 30 species, from 11 families of the order Coleoptera (23 species) and Hemiptera (7 species) in the GSKBB-BR. The diversity index of Coleoptera and Hemiptera at the observation site was moderate $(H=2.73)$, with a high evenness index (0.80). Scarabaeidae (order Coleoptera) is the family with the highest number of species found (8 species), while the most abundant species were Tibicen linnei and Pomponia fusca (Cicadidae/Hemiptera). Based on their functional roles, Coleoptera and Hemiptera with the highest number are herbivores (17 species), followed by predators (7 species) and decomposers (3 species). The range of values for temperature and humidity at the research site are in normal conditions. The GSKBB-BR area is an important remaining habitat for wildlife in Riau, including various types of insects (Coleoptera and Hemiptera); whose potential still needs to be revealed, and must be managed properly.
\end{abstract}

Keywords: biodiversity, Coleoptera, Giam Siak, Hemiptera, Riau

\section{Citation}

Ruslan, H. \& Tobing, I. S. L. (2021). Nokturnal Coleoptera and Hemiptera Diversity Giam Siak Kecil Bukit Batu Biosphere Reserve Indonesia. Jurnal Biodjati, 6(2), 312-318.

\section{INTRODUCTION}

Giam Siak Kecil Bukit Batu (GSKBB) is the 7 th biosphere reserve in Indonesia, which functions toconserve biodiversity. This area has abundant biodiversity, an important factor in maintaining the balance of nature for the sustainability of the ecosystem. The GSKBB Biosphere Reserve was declared relatively new, in 2009; Thus its biodiversity has not much been revealed. Therefore, it is very necessary for studies that aim to reveal the richness of biodiversity in the GSKBB
Biosphere Reserve, Riau, Indonesia, including insect species from the orders Coleoptera and Hemiptera.

Insects have the largest number of species in nature, and its various species are keystones in the ecosystem. Some act as pollinators, predators, detritivores, and some can be used as bioindicators (Triplehorn \& Johnson 2005; de Farias \& Hernandez, 2017), although some species are also parasitic. Some of the pollinating insects (Coleoptera) are Elaeidobius kamerunicus (Yue et al., 2015; Yousefi et al., 2020); predatory 


\section{JURNAL BIDDJATI}

http://journal.uinsgd.ac.id/index.php/biodjati

insects, such as Micraspis sp (Coleoptera), Cyrtorhinus lividipennis (Hemiptera) (Azima et al., 2017); detritivores such as the white grub (Phillophaga sp.) and the juni beetle (Phyllophaga portoricensis) (Coleoptera) (Imaculata, 2021). Some species can also be used as bioindicators (Parikh et al., 2021), such as Ambrysus sp. (Hemiptera); or several species from the family Belostomatidae (Hemiptera) for heavy metal pollution (Corby et al., 2011).

Insect diversity has never been reported in the GSKBB biosphere reserve. This area is inhabited by various protected, endangered, and listed species in the CITES Appendix, both plants and animals. The results of the LIPI study (2009) in this area identified at least 10 species of mammals, 159 species of birds, 8 species of reptiles, and 13 species of fish; 52 species of plants with rare and protected status were also recorded, but no information about insects at all. Therefore, this research was carried out to determine the diversity of insects (Coleoptera and Hemiptera) in the GSKBB biosphere reserve area.

\section{MATERIALS AND METHODS}

The sampling method conducted comply with the quantitative descriptive method, using lights trap on a plot of $10 \times 10$ meters. The research was conducted on May $5^{\text {th }}-11^{\text {th }} 2021$. The trapping period was from 19:00-23:00, for 3 consecutive nights. The instruments used for sampling were alcohol $70 \%$, plastic bags, tweezers, killing bottle, magnifier, label paper, GPS, and identification book. Environmental factors were also gathered includes air temperature and humidity. The data were analyzed to determine the diversity index, evenness index, and dominance index of nocturnal insects of the order Coleoptera and Hemiptera in the

Ruslan \& Tobing study area. The species diversity index was calculated using the Shannon-Wiener diversity index $\left(\mathrm{H}^{\prime}\right)$. Evenness of species at a location was calculated using the formula according to Magurran (1988). The dominance index was used to determine the dominant and non-dominant species, the formula used was according to Odum (1993).

\section{RESULTS AND DISCUSSION}

\section{Composition of Nocturnal Coleoptera and}

\section{Hemiptera.}

The results on the diversity of nocturnal Coleoptera and Hemiptera around the Giam Siak Kecil Bukit Batu Biosphere Reserve Indonesia found 30 species, 11 families, and 112 individuals (Table 1). The Scarabaeidae family is one of the families with the highest number of species found, namely 8 species. The existence of Scarabaiedae in a habitat is related to several things such as the presence of other organisms producing dirt that acts as a food source and the type of bushy vegetation which generally found as a residence for Scarabaeidae (Sundari, 2018). Secondary forest, the observation location in this study is one of the conducive habitat for Scarabaeidae.

Among 112 individuals found, there are some species that are dominating in numbers which are Tibicen linnei and Pomponia fusca. While the species with the lowest number are Cicindela aurulenta, Cicindela sp, Acalepta montana, Accalolepta Aesthetica, Ceratocentrus principiensis, Xystrocera virescens, Hylobius pales, Cryptalaus brush, Geotrupes splendidus, Prosopocoilus astacoides, chatarsius mollosus, Xytrocera festiva, and Reduviidae sp 1. The composition of Coleoptera in this habitat is strongly influenced by overall vegetation and environmental conditions, as well as the size 


\section{JURNAL BIODJATI}

http://journal.uinsgd.ac.id/index.php/biodjati

of the sampling area (Riyanto, 2016). The presence and number of insects in a habitat could be influenced by various factors, including food resources, environmental conduciveness, human disturbance, and other natural enemies. Thus, spurring insects to implement strategies to maintain the sustainability of their species in nature, including regulating the number of offspring (Speight et al. 2008).

Table 1. Numbers of nocturnal spesies Coleoptera and Hemiptera found at the Giam Siak Kecil Bukit Batu Biosphere Reserve

\begin{tabular}{|c|c|c|c|c|c|c|}
\hline Ordo & Family & Species & I & II & III & Total \\
\hline \multirow[t]{23}{*}{ Coleoptera } & Carabidae & Mormolyce phyllodes & 0 & 0 & 2 & 2 \\
\hline & & Cicindela aurulenta & 0 & 1 & 0 & 1 \\
\hline & & Cicindela $\mathrm{sp}$ & 0 & 0 & 1 & 1 \\
\hline & Cerambycidae. & Acalepta montana & 1 & 0 & 0 & 1 \\
\hline & & Accalolepta aesthetica & 0 & 0 & 1 & 1 \\
\hline & & Ceratocentrus principiensis & 0 & 1 & 0 & 1 \\
\hline & & Xystrocera virescens & 0 & 0 & 1 & 1 \\
\hline & & sp1 & 1 & 2 & 0 & 3 \\
\hline & Curculionidae & Hylobius pales & 0 & 0 & 1 & 1 \\
\hline & Elateridae & Cryptalaus berus & 1 & 0 & 0 & 1 \\
\hline & & Oxynopterus audouini & 1 & 0 & 1 & 2 \\
\hline & & Oxynopterus mucronatus & 0 & 2 & 0 & 2 \\
\hline & Geotrupidae & Geotrupes splendidus & 1 & 0 & 0 & 1 \\
\hline & Lucanidae & Prosopocoilus astacoides & 0 & 1 & 0 & 1 \\
\hline & Melandryidae & Emmesa labiata & 0 & 0 & 2 & 2 \\
\hline & Scarabaeidae & Anomala dimidiata & 1 & 2 & 1 & 4 \\
\hline & & Apogonia sp & 2 & 2 & 0 & 4 \\
\hline & & Chalcosoma atlas & 0 & 2 & 0 & 2 \\
\hline & & Chalcosoma caucasus & 1 & 0 & 1 & 2 \\
\hline & & chatarsius mollosus & 0 & 1 & 0 & 1 \\
\hline & & Exopholis hypoleuca & 1 & 0 & 1 & 2 \\
\hline & & Oryctes rhinoceros & 3 & 2 & 2 & 7 \\
\hline & & Xytrocera festiva & 0 & 1 & 0 & 1 \\
\hline \multirow[t]{7}{*}{ Hemiptera } & Cicadidae & Dundubia vaginata & 0 & 4 & 2 & 6 \\
\hline & & Pomponia fusca & 5 & 2 & 4 & 11 \\
\hline & & Platylomia flavida & 2 & 3 & 3 & 8 \\
\hline & & Pomponia sp & 1 & 1 & 2 & 4 \\
\hline & & Tibicen linnei & 12 & 14 & 8 & 34 \\
\hline & Alydidae & Leptocorisa acuta & 1 & 0 & 3 & 4 \\
\hline & Reduviidae & spl & 0 & 1 & 0 & 1 \\
\hline Total & & & 34 & 42 & 36 & 112 \\
\hline
\end{tabular}

The high number of cicadas species such as Tibicen linnei and Pomponia fusca found in this study is thought to be related with their social function as a season change indicator which usually occurs in April-May (Anonym, Jurnal Biodjati 6(2):312-318, November 2021
2017). Cicadas will generally appear during the summer. And at this time of season change, the sound of cicadas is frequently heard (Raup et al., 2004). 


\section{JURNAL BIDDJATI}

http://journal.uinsgd.ac.id/index.php/biodjati

\section{Species Diversity and Evenness Index}

Based on the diversity index value, it is revealed that the diversity index value of nocturnal Coleoptera and Hemiptera insects at the observation site is classified as moderate $(\mathrm{H}=2.73)$. The index value of insect diversity in a habitat can be related to the stability of the ecosystem related to resources (Sumarmiyati et al., 2019). The moderate diversity index value obtained in this study indicates that the food resources in the form of diverse vegetation, the presence of natural enemies as controllers of certain populations, and the conduciveness of habitats as shelters and lives that tend to be more stable. The diversity index value is also influenced by the ability of insects to reproduce (Jumar, 2000), vegetation composition, and the diversity of stand structures (Kasmiatun, 2020).

The evenness index value obtained in this study was 0.80 , categorized as a high evenness of species. The high evenness index value at the sampling location indicates that no individual dominates at the sampling location. According to Odum (1993), an abundance of evenness index represent that individuals were found evenly (no dominant). From the calculation results obtained dominance index was 0.12 . This is in accordance with the criteria Odum (1993), that the value of dominance index 0.12 represent low dominance.

\section{Functional Role}

Based on their functional roles, the nocturnal Coleoptera and Hemiptera obtained were grouped into 5; predators, herbivores, detritivores, mycophagous, and decomposers (Table 2). Meanwhile, based on the number of individuals, it is known that herbivorous insects have the highest number compared to other insects (Figure 1).

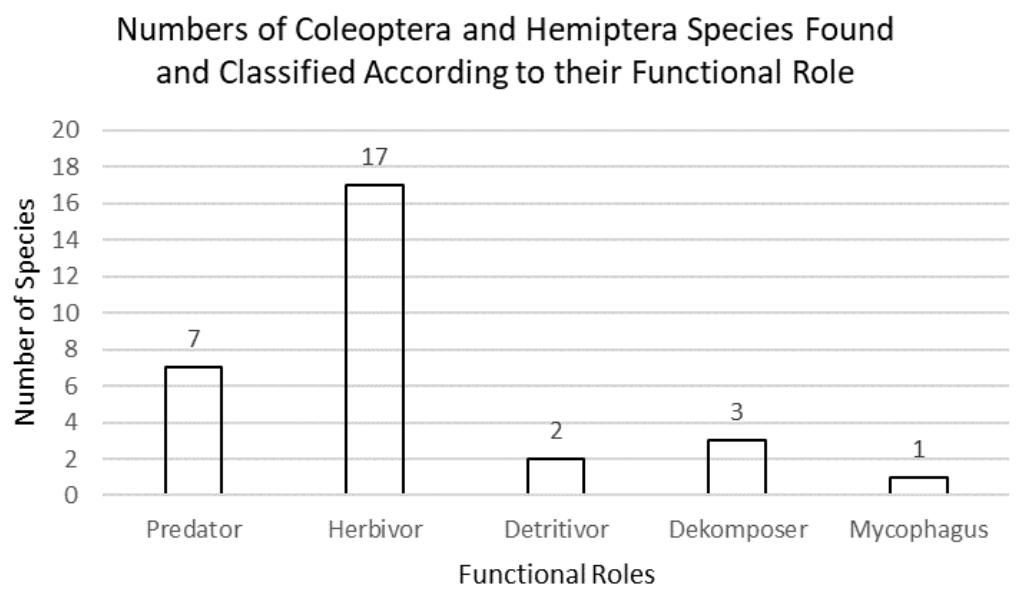

Figure 1. Comparison graph of number Coleoptera and Hemiptera found based on of their functional roles

The high population of Coleoptera and Hemiptera insects that play a role as herbivores can be caused by the conduciveness of resources for these insect populations. High vegetation diversity is known as one of the factors that contribute to the high number of Ruslan \& Tobing herbivorous insects in a community (Rahayu et al., 2017). The diversity of plant affects the diversity and composition of Coleoptera (Apigian et al., 2006). The increasing diversity of Hemiptera is aligned with the increase diversity of plants (Mata L, 2013). 


\section{JURNAL BIODJATI}

http://journal.uinsgd.ac.id/index.php/biodjati

In addition, Hamid (2012) stated that the population of herbivorous insects can exist with a high number of individuals due to the absence of a population-suppressing factor which is its natural enemies. The appearance of several species at certain periodicals such as the cicadas group that appears coincides with the observation as well.

Table 2. Functional roll of nocturnal Coleoptera dan Hemiptera

\begin{tabular}{|c|c|c|c|}
\hline Ordo & Family & Species & Role \\
\hline \multirow[t]{23}{*}{ Coleoptera } & Carabidae & Mormolyce phyllodes & Predator \\
\hline & Carabidae & Cicindela aurulenta & Predator \\
\hline & Carabidae & Cicindela sp & Predator \\
\hline & Cerambycidae & Acalepta montana & Herbivor \\
\hline & & Accalolepta aesthetica & Herbivor \\
\hline & & Ceratocentrus principiensis & Herbivor \\
\hline & & Xystrocera virescens & Herbivor \\
\hline & & sp1 & Herbivor \\
\hline & Curculionidae & Hylobius pales & Detritivor \\
\hline & Elateridae & Cryptalaus berus & Predator \\
\hline & & Oxynopterus audouini & Predator \\
\hline & & Oxynopterus mucronatus & Predator \\
\hline & Geotrupidae & Geotrupes splendidus & Mycophagus \\
\hline & Lucanidae & Prosopocoilus astacoides & Detritivor \\
\hline & Melandryidae & Emmesa labiata & Herbivor \\
\hline & Scarabaeidae & Anomala dimidiata & Herbivor \\
\hline & Scarabaeidae & Apogonia sp & Herbivor \\
\hline & Scarabaeidae & Chalcosoma atlas & Dekomposer \\
\hline & Scarabaeidae & Chalcosoma caucasus & Dekomposer \\
\hline & Scarabaeidae & Chatarsius mollosus & Dekomposer \\
\hline & Scarabaeidae & Exopholis hypoleuca & Herbivor \\
\hline & Scarabaeidae & Oryctes rhinoceros & Herbivor \\
\hline & Scarabaeidae & Xytrocera festiva & Herbivor \\
\hline \multirow[t]{7}{*}{ Hemiptera } & Cicadidae & Dundubia vaginata & Herbivor \\
\hline & & Pomponia fusca & Herbivor \\
\hline & & Platylomia flavida & Herbivor \\
\hline & & Pomponia sp & Herbivor \\
\hline & & Tibicen linnei & Herbivor \\
\hline & Alydidae & Leptocorisa acuta & Herbivor \\
\hline & Reduviidae & $s p 1$ & Predator \\
\hline
\end{tabular}

\section{Abiotic Factors}

The range of temperature and humidity values found at the study site were in normal conditions and conducive to the development of various types of insects (in average $82 \%$ and $25.5^{\circ} \mathrm{C}$ respectively). Taradipha et al. (2019) stated that insects can still live and reproduce well in habitats with abiotic components in a normal range of values. The normal temperature range for insects ranges from $15^{\circ} \mathrm{C}-45^{\circ} \mathrm{C}$ ( Jumar, 2000), while the ideal humidity can range from $70-100 \%$. 


\section{JURNAL BIODJATI}

http://journal.uinsgd.ac.id/index.php/biodjati

The results of this study found 30 species, 11 families, and 112 individuals of nocturnal Coleptera and Hemiptera at Giam Siak Kecil. The family with the highest variety of species found at the location was scarabaeidae. Species found in high numbers were Tibicen linnei, and Pomponia fusca. The diversity index of nocturnal Coleoptera and Hemiptera at the observation site was classified as moderate $(H=2.73)$. The evenness index value obtained in this study was 0.80 mand classified as high category. Based on their functional roles, nocturnal Coleoptera and Hemiptera have the highest number of herbivores. The range of values for air temperature and humidity in the research location are in normal conditions.

\section{ACKNOWLEDGEMENTS}

This report is one of the obligations for lecturers (researchers) and receive stimulus funds from the Universitas National (SK No: 36 Tahun 2020). This research would have not carried out properly without support from various parties. Therefore, on this occasion we would like to express our gratitude to Ernawati Sinaga as Vice Rector of Research and Community of LPPM UNAS, Imran Tobing as the Dean of Faculty of Biology at National University, PT APP Sinarmas and PT Sakato for all of their permission, assistance, and support during conducting this research.

\section{REFERENCES}

Anonym. (2017). Sejauh Apa Kita Mengenal Cicada (Tonggeret) di Indonesia?. Departemen Hama dan Penyakit Ruslan \& Tobing
Tumbuhan, Universitas Gajah Mada. Retrieved from . https://hpt.faperta. ugm.ac.id/sejauh-apa-kita-mengenalcicada-tonggeret-di-indonesia/

Apigian K. O, Dahlsten D. L. \& Stephens, S. L. (2006). Biodiersity of Coleoptera and the Importance of Habitat Structural Features in a Sierra Nevada MixedConifer Forest. Environ. Entomol. 35 (4) : 964-975.

Azima, S. E., Syahribulan, S, S. \& Santosa S. (2017). Analisis Keragaman Jenis Serangga Predator pada Tanaman Padi di Areal Persawahan Kelurahan Tamalanrea Kota Makassar (Analysis of Biodiversity of Predator Insect in Paddy Field at Tamalanrea of Makassar City). Bioma: Jurnal Biologi Makasar, 2(2), 12-18.

Corby, J.J., Froehlich, C.G., TrivinhoStrixino, S. \& Dos Santos, A., (2011), Evaluating the Sse of Predatory Insects as Bioindicators of Metals Contamination Due to Sugarcane Cultivation in Neotropical Streams. Environ Monit Assess, 177, 545-554.

de Farlas, P. M. \& Hernandez, M. I. M. (2016). Dung Bettles Associated with Agroecosystems of Southern Brazil : Relationship with Soil Properties. Rev Bras Cienc Solo. 41, 1-13.

Magurran, A. E. (2004). Measuring Biological Diversity. Oxford: Blackwell Publishing.

Hamid, H. (2012). Struktur Komunitas Serangga Herbivora dan Parasitoid pada Polong Tanaman Kacangkacangan (Fabaceae) di Padang. Jurnal Entomologi Indonesia, 9 (2), 88-94.

Imaculata, M. M. (2021). Karakteristik Morfologi Detrivor pada Sampah organik di Kelurahan Tarus Kecamatan Kupang Tengah Kabupaten Kupang. 


\section{JURNAL BIODJATI}

http://journal.uinsgd.ac.id/index.php/biodjati

Media Sains, 21(1), 42-55.

Jumar. 2000. Entomologi Pertanian. Jakarta:

Rineka Cipta

Kasmiatun, Nazzareta, R. \& Buchori, D. (2020). Keanekaragaman dan Komposisi Kumbang Elaterid (Coleoptera: Elateridae) di Kawasan Hutan Hujan Tropis Taman Nasional Bukit Duabelas dan Hutan Harapan, Jambi. Jurnal Entomologi Indonesia, 17(1), 33-44.

LIPI. (2009). Indonesia Lahirkan Cagar Biosfer Baru di Giam Siak Kecil-Bukit Batu, Riau. Retrieved from http://lipi. go.id/siaranpress/indonesia-lahirkancagar-biosfer-baru-di-giam-siak-kecilbukit-batu-riau/13353.

Mata, L. (2013). Heteroptera Ecology, Biodiversity and Conservation. Disertasi. Universitat de Barcelona.

Dasar-dasar Ekologi. Terjemahan Tjahjono Samingan, 3th Edition. Yogyakarta: Gadjah Mada University Press

Parikh G, Rawtani D, \& Khatri N. 2021. Insects as an Indicator for Environmental Pollution. Environmental Claims Journal, 33(2), 161-181.

Rahayu. G. A., Buchori, D., Hindayana, D. \& Rizali, A (2017). Keanekaragaman dan Peran Fungsional Serangga Ordo Coleoptera di Area Reklamasi Pascatambang Batubara di Berau, Kalimantan Timur. Jurnal Entomologi Indonesia, 14(2), 97-106.

Raup, M. R., Wood,F. E., Davidsion, J. A. \& Hellmans, J. L. (2004). Periodical Cicadas. Revised: Menninger, H. \& Frank,S. (2004). USA: Dept. of Biology \& Entomology, University of Maryland University of Maryland

Riyanto. (2016). Keanekaragaman dan Kelimpahan Serangga Ordo Coleoptera di Tepian Sungai Musi Kota Palembang sebagai Sumbangan Materi pada Mata
Kuliah Entomologi di Pendidikan Biologi FKIP Universitas Sriwijaya. Jurnal Pembelajaran Biologi, 3(1), 88100.

Speight, M. R., Hunter, M. D. \& Watt, A. D. (2008). Ecology of Insects: Concepts and Applications, 2nd ed. WilleyBlackwell

Sumarmiyati, Handayani, F. \& Sundari. (2019). Keragaman Serangga pada Pertanaman Padi Sawah di Kabupaten Kutai Kartanegara, Kalimantan Timur. Pros Sem Nas Masy Biodiv Indon, 5 (2), 217-221.

Sundari T. (2018). Keanekaragaman Jenis Ordo Coleoptera pada Pertanaman Sayuran di Kecamatan Jambi Selatan Kota Jambi. Artikel. Jambi: Prodi Biologi, Universitas Jambi

Yue, J., Yan, Z., Bai, C., Chen, Z., Lin, W. \& Jiao F. (2015). Pollination Activity of Elaeidobius Kamerunicus (Coleoptera: Curculionoidea) on Oil Palm on Hainan Island. Florida Entomologist, 98(2), 499-505.

Taradipha, M. R. R. (2019). Karakteristik Lingkungan terhadap Komunitas Serangga. Jurnal Pengolahan Sumber daya Alam dan Lingkungan, 9(2), 394404.

Triplehorn, C. A. \& Johnson, N. F. (2005). Borror and DeLong's Introduction to Study of Insect 7th edition. US: Cengange Learning, Stanford.

Yousefi, M,. Shakrine, A., Rafie, M., Aziz, S. A., Azrad, A. \& Razak, A. A. (2020). Introduction of Current Pollination Techniques And Factors Affecting Pollination Effectiveness By Elaeidobius Kamerunicus in Oil Palm Plantations on Regional and Global Scale: a Review. South African Journal of Botany, 132, 171-179. 